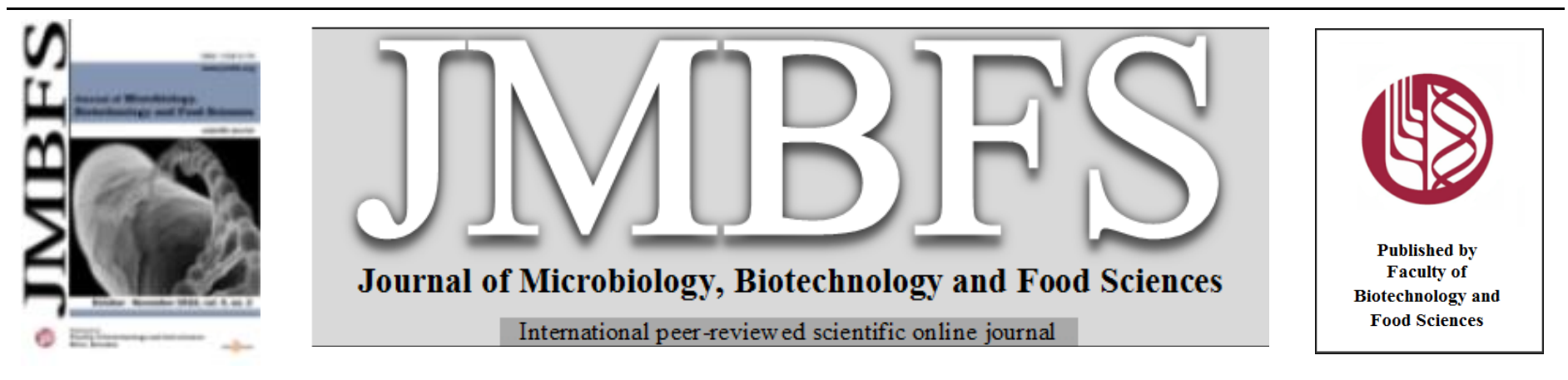

\title{
QUANTITATIVE PROTEASE ASSAY BY SUBSTRATE-AGAROSE PLATE METHOD
}

\section{Narendra U. Mokashe, Ulhas K. Patil*}

Address(es): Dr. Ulhas K. Patil,

Department of Microbiology, R. C. Patel Arts, Commerce and Science College, Shirpur, Dist - Dhule (M.S.) India, 425405, Tel.: +91 2563 257328 ; fax: +91 2563 255189 .

*Corresponding author: ulhaskpatil@gmail.com

doi: 10.15414/jmbfs.2016.6.2.791-793

\section{ARTICLE INFO}

Received 13. 1. 2016

Revised 12. 5. 2016

Accepted 12. 7. 2016

Published 3. 10. 2016

Short communication open $\partial_{\text {ACCESS }}$

\begin{abstract}
Proteases are unique class of industrial biocatalyst; occupy a key chair with respect to wide range of utility in both physiological and commercial sector. Repertoire of various enzyme assays were suggested for determining enzyme units of protease. Majority of currently reported assays are expensive, time consuming and cumbersome. In this direction, a development of speedy and sensitive quantitative enzyme assay for the characterization of proteases is highly desirable. The present investigation reported a quick method for characterization of proteases using single substrate-agarose plate method. A trypsin (obtained from bovine pancreas) and bacterial protease (serine protease of Bacillus circulans MTCC 7942) on subsequent interaction with proteinaceous substrate gives proteolytic zone on substrate-agarose plate. The clear zone diameter of proteolysis was directly proportional to enzyme units of protease. Furthermore, enzyme activities of protease treated with various chemical activator/inhibitor gives vis-à-vis response and yielded significant data. The biochemical characteristics of proteases are documented using rapid single substrate-agarose plate method. A rapid, sensitive and reliable improved quantitative protease assay using single substrate-agarose plate method could be used at academic, research and commercial level.
\end{abstract}

Keywords: Characterization, Protease, Proteinaceous substrate, Substrate-agarose plate

\section{INTRODUCTION}

The biotechnological applications of proteases are rapidly growing as the proteases with novel properties and wide substrate specificities were documented in recent years (Li et al., 2013). Proteases are physiologically important, as $\sim 2 \%$ genes codes for proteases in each organism (Barrett and Rawlings, 2001) Proteases capable of functioning at extreme $\mathrm{pH}(3-11)$, temperature $\left(40-80^{\circ} \mathrm{C}\right)$ and in organic solvents are considered as robust proteases and suitable for industrial applications. Currently, thermo-, organic solvent stable, alkaline proteases were preferred for various industrial and therapeutic applications (Patil and Chaudhari, 2010; Li et al., 2013).

In order to evaluate the commercial utility of newly reported protease, it should be characterized. The characterization of protease from newly reported source includes (i) knowing their active $\mathrm{pH}$ and thermal range; (ii) revealing their functional type; (iii) understanding their robustness against oxidizing-, reducing-, bleaching agents, organic solvents and detergents. On the basis of these characteristics, the suitability of protease is determined for commercial applications. As well, type of protease secreted by pathogenic strains could offer a clue about the role of protease in the pathogenesis of infectious diseases (Jarocki et al., 2015).

Currently proteases were assayed by arrays of quantitative approaches, which measure hydrolytic products of either proteinaceous substrate or residual fragmented peptides. These methods usually vary in their simplicity, rapidity, sensitivity, range of detection and cost per test. The routinely used quantitative assay methods for protease activity involves the use of natural or synthetic substrates by employing spectrophotometric, fluorimetric, radiometric and enzyme-linked immunosorbent assay (ELISA) (Sumantha et al., 2006). An absorption spectroscopy is widely used for protease assay (Mokashe et al., 2015).

Pioneering contributions of Anson (1938) and Kunitz (1947) in protease assay was further modified by several investigators (Nakanishi et al., 1974; Shimogaki et al., 1991). The majority of protease assay involves incubation of protease with proteinaceous substrate for a specific period. On subsequent trichloroacetic acid reagent (TCA) precipitation, the fragmented residual peptides were determined by (i) measuring the absorbance at $275-280 \mathrm{~nm}$ using tyrosine $(0-75 \mu \mathrm{g} / \mathrm{mL}$ ) as a standard; (ii) Folin-Lowry method or (iii) analyzing the nitrogen of fragmented peptides by Kjeldahl method. Although, the continuous monitoring of time-dependent progressions of enzyme reactions make these methods attractive, but stressed handling, cumbersome additions and reagent/buffer preparations are several hurdles in the routine protease assay. In this view, there is a scope for a development of rapid and sensitive quantitative enzyme assay for the characterization of proteases.

Generally, protease producing microbes/biological source was detected by assessing the proteolytic zone on casein, gelatin, skimmed/lactose free milk agar plate (Vermelho et al., 1996; Morris et al., 2012). Furthermore, agents like Bradford reagent and bromocresol green dye were suggested for detecting very narrow proteolysis zones clearly (Lu et al., 2013; Vijayaraghavan and Vincent, 2013). Also, Montville (1983) reported the dual-substrate plate diffusion assay for characterization of endopeptidases by correlating the proteolytic zone diameter and enzyme activity. Although, these approaches were commonly used for qualitative detection of the protease, few investigators have utilized this principle for quantitative protease assay (Gallahgher $\boldsymbol{e t}$ al., 1986). The method reported here describes quantitative enzyme assay by employing single substrateagarose plate without use of a detection reagents (Coomassie Blue dye/TCA). A gel-diffusion method was legitimately described for quantitative estimation of antibiotics/vitamins (Indian pharmacopoeia, 2014). Such gel-diffusion method determines the potency of antibiotic/vitamin rather than its quantity. Likewise, an optimized procedure could be able to quantify the enzyme activity (units) by employing gel-diffusion principles. The method suggested in this investigation describes simple, rapid and quantitative noteworthy enzyme assay for characterizing the protease using substrate-agarose plate.

\section{MATERIALS AND METHODS}

\section{Enzymes}

The proteases used in this study were - purified alkaline serine protease of Bacillus circulans MTCC 7942 (Patil et al., 2016) and commercial trypsin (EC 3.4.21.4, MP Biomedicals, USA; obtained from bovine pancreas). 


\section{Protease assay}

Protease activity was assayed as per Anson-Hagihara (Hagihara, 1958) using buffered casein as a substrate. Bacterial alkaline serine protease assay was conducted at $60^{\circ} \mathrm{C}$ using casein prepared in $20 \mathrm{mM}$ carbonate-bicarbonate buffer (pH 10), while trypsin assay was conducted at $37^{\circ} \mathrm{C}$ using casein; prepared in $100 \mathrm{mM}$ Tris buffer ( $\mathrm{pH} 7.5$ ). One unit of bacterial alkaline protease activity was defined as the amount of enzyme required to produce peptides equivalent to $1 \mu \mathrm{g}$ of tyrosine in the filtrate per minute per $\mathrm{ml}$ at $\mathrm{pH} 10$ and $60{ }^{\circ} \mathrm{C}$. Similarly, one unit of trypsin activity was defined as the amount of enzyme required to produce peptides equivalent to $1 \mu \mathrm{g}$ of tyrosine in the filtrate per minute per $\mathrm{ml}$ at $\mathrm{pH} 7.5$ and $37^{\circ} \mathrm{C}$

\section{Casein-agarose plate preparation}

Casein-agarose plates with medium (g/L) containing skim milk, 28 and agarose 20 in $20 \mathrm{mM}$ carbonate-bicarbonate buffer $(\mathrm{pH} \mathrm{10)}$ for bacterial serine protease plate assay and $100 \mathrm{mM}$ Tris buffer $(\mathrm{pH} \mathrm{7.5)}$ for trypsin plate assay was used. The casein-agarose media was autoclaved at $121{ }^{\circ} \mathrm{C}$ for $5 \mathrm{~min}$. The medium was subsequently degassed using sonication for $5 \mathrm{~min}$ in ultrasonic cleaning bath (33 $\mathrm{kHz}$ ) (Equitron, Medica Instrument Mfg. Co., Mumbai) and poured (thickness $3.1 \mathrm{~mm})$ in sterile disposable square petri plate $(120 \mathrm{~mm} \times 120 \mathrm{~mm})$. Then $\sim 25$ wells (diameter $-6 \mathrm{~mm}$ ) were punched on solidified casein-agarose plates.

\section{Substrate-agarose plate method}

To optimize the substrate-agarose plate enzyme assay, a standard graph of enzyme activity versus zone of proteolysis was determined. For this, $80 \mu \mathrm{L}$ purified protease aliquot (Bacterial serine protease $40-440 \mathrm{U} / \mathrm{mL}$ and trypsin 20 $240 \mathrm{U} / \mathrm{mL}$ ) was loaded on punched experimental wells in casein-agarose plate These plates were incubated precisely for $8 \mathrm{~h}$ at $60^{\circ} \mathrm{C}$ and $37^{\circ} \mathrm{C}$, respectively. After incubation, plates were observed for the zone of proteolysis and zone diameters were determined using vernier caliper (Mitutoyo, Digimatic Caliper, Japan). Each experiment was conducted in triplicates.

\section{Enzyme characterization by Substrate-agarose plate method}

The respective enzyme aliquots were further allowed to interact with various activators, inhibitors and stabilizers to characterize the biochemical nature of enzyme. The substrate-agarose plate method described as above was employed to determine the residual activity of the enzyme on subsequent treatment with activators, inhibitors, stabilizers and organic solvents. For this, various salt solutions $\left[\mathrm{NaCl}, \mathrm{KCl}, \mathrm{MgCl}_{2}, \mathrm{CaCl}_{2}, \mathrm{MnCl}_{2}, \mathrm{ZnCl}_{2}, \mathrm{CuCl}_{2}, \mathrm{CdCl}_{2}\right.$ and $\mathrm{HgCl}_{2}$ (5 $\mathrm{mM})$ ]; surfactants (1\% sodium dodecyl sulfate and $1 \%$ Triton $\mathrm{X}-100)$, protease inhibitors (5 mM) - phenyl-methyl-sulfonyl-fluoride (PMSF), N-ethyl-maleimide, ethylene-diamine-tetra-acetic acid (EDTA) and organic solvents (acetone, benzene, butanol, chloroform, dimethyl sulfoxide, glycerol, pyridine, $n$-dodecane and toluene) were interacted with respective enzyme solutions. After preincubation $\left(1 \mathrm{~h}\right.$ at $\left.27^{\circ} \mathrm{C}\right)$ respective mixture was loaded in labeled well of caseinagarose plate. The loaded plates were further incubated for $8 \mathrm{~h}$ at a respective optimum temperature of the enzyme.

\section{RESULTS AND DISCUSSION}

The caseinolytic activity of trypsin/bacterial protease was compared with the zone of proteolysis on casein-agarose plate. A standard curve of trypsin activity versus zone of proteolysis was plotted (Figure 1). Protease activities (U/mL) and zones of proteolysis on casein-agarose plate were found to be positively correlated. The Pearson correlation coefficient of standard curve for bacteria serine alkaline protease and trypsin were 0.9694 and 0.9469 , respectively. Several experimental attempts have been undertaken with a view to quantitate the enzyme units by substrate-agarose assay method. Also, the F-test is used to compare variances in newly reported substrate-agarose assay and known assay (Anson-Hagihara protease assay method) to determine significant differences in precision of two methods. The calculated $\mathrm{F}$ value is 1.1 , while the tabulated Fvalue is 4.28 , indicating no significant difference in precision of two methods.

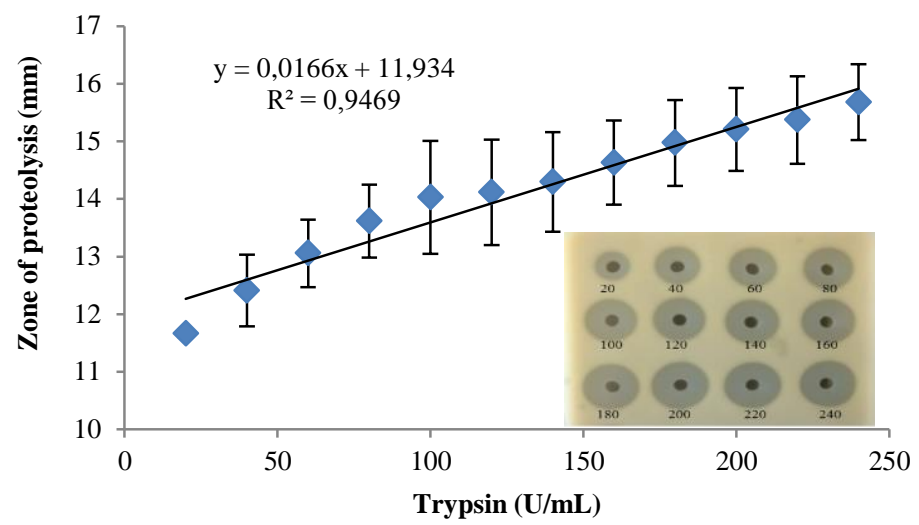

Figure 1 Standard curve for trypsin

Based on proteolysis zones formed by respective treated bacterial serine protease (Figure 2) and trypsin (Figure 2) the residual enzyme activities were determined. The equations to determine enzyme activity are as follows-

$/ 0.0119$

Bacterial protease activity $(\mathrm{U} / \mathrm{mL})=($ Proteolysis zone in $\mathrm{mm}-9.93)$

Trypsin activity $(\mathrm{U} / \mathrm{mL})=($ Proteolysis zone in $\mathrm{mm}-11.93) / 0.0166$.
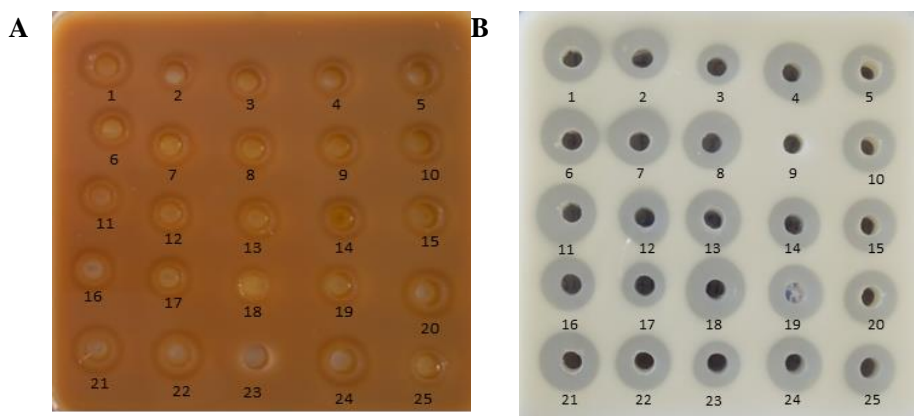

Figure 2 (A) Proteolysis zones by treated alkaline protease of Bacillus circulans MTCC 7942 on single substrate-agarose plate (pH 10): 1) Control, 2) PMSF (5 $\mathrm{mM})$, 3) Pyridine, 4) Benzene, 5) $\left.\mathrm{MgCl}_{2}, 6\right) \mathrm{NaCl}(5 \mathrm{mM})$, 7) $\mathrm{KCl}$, 8) Butanol, 9) $n$-dodecane, 10) $\mathrm{NaCl}(150 \mathrm{mM}), 11)$ Glycerol, 12) SDS, 13) DMSO, 14) $\mathrm{ZnCl}_{2}$, 15) $\mathrm{CuCl}_{2}$, 16) $\mathrm{CdCl}_{2}$, 17) $\mathrm{HgCl}_{2}$, 18) Toluene, 19) Chloroform, 20) $\mathrm{CaCl}_{2}$, 21) Triton $\left.\mathrm{X}-100,22\right)$ EDTA, 23) PMSF (10 mM), 24) N-ethyl maleimide, 25) Acetone, (B) Proteolysis zones by treated trypsin on single substrate-agarose plate ( $\mathrm{pH} 7.5)$ : 1) Control, 2) $\mathrm{HgCl}_{2}$, 3) Pyridine, 4) Benzene, 5) $\mathrm{MgCl}_{2}$, 6) $\mathrm{NaCl}(5 \mathrm{mM})$, 7) $\mathrm{KCl}$, 8) Butanol, 9) PMSF (10 mM), 10) $\mathrm{NaCl}$ (150 mM), 11) Glycerol, 12) SDS, 13) DMSO, 14) $\left.\mathrm{ZnCl}_{2}, 15\right) \mathrm{CuCl}_{2}$, 16) $\mathrm{CdCl}_{2}$, 17) PMSF (5 mM), 18) Toluene, 19) Chloroform, 20) $\left.\mathrm{CaCl}_{2}, 21\right)$ Triton $\mathrm{X}-100$, 22) EDTA, 23) $n$-dodecane, 24) N-ethyl maleimide, 25) Acetone.

The enzyme activities determined using substrate-agarose assays were in agreement with Anson-Hagihara protease assay method. Also, these findings were in agreement with previous reports on characterization of bacterial serine protease from Bacillus circulans MTCC 7942 (Table 1) and trypsin (Table 2) (Blanco et al., 2014; Patil et al., 2016).

Table 1 Proteolytic zones on single substrate-agarose plate and corresponding protease activities of treated serine alkaline protease of Bacillus circulans MTCC 7942

\begin{tabular}{|c|c|c|c|}
\hline \multirow{2}{*}{$\begin{array}{l}\text { Sr. } \\
\text { No. }\end{array}$} & \multirow{2}{*}{$\begin{array}{l}\text { Activator/ inhibitor/organic } \\
\text { solvents/salts }\end{array}$} & \multicolumn{2}{|c|}{$\begin{array}{c}\text { Alkaline serine protease of Bacillus } \\
\text { circulans MTCC } 7942\end{array}$} \\
\hline & & $\begin{array}{l}\text { Zone of proteolysis } \\
(\mathrm{mm})\end{array}$ & $\begin{array}{c}\text { Protease activity } \\
(\mathrm{U} / \mathrm{mL})\end{array}$ \\
\hline 1. & Control & 13.93 & 335.88 \\
\hline 2. & PMSF (5 mM) & 10.12 & 15.71 \\
\hline 3. & Pyridine & 11.24 & 109.83 \\
\hline 4. & Benzene & 11.29 & 114.03 \\
\hline 5. & $\mathrm{MgCl}_{2}$ & 12.82 & 242.61 \\
\hline 6. & $\mathrm{NaCl}(5 \mathrm{mM})$ & 12.76 & 237.56 \\
\hline 7. & $\mathrm{KCl}$ & 12.72 & 234.20 \\
\hline 8. & Butanol & 11.45 & 127.48 \\
\hline 9. & $n$-dodecane & 12.36 & 203.95 \\
\hline 10. & $\mathrm{NaCl}(150 \mathrm{mM})$ & 11.93 & 167.82 \\
\hline 11. & Glycerol & 12.4 & 205.63 \\
\hline 12. & SDS & 11.84 & 160.25 \\
\hline 13. & DMSO & 12.4 & 207.31 \\
\hline 14. & $\mathrm{ZnCl}_{2}$ & 11.63 & 142.61 \\
\hline 15. & $\mathrm{CuCl}_{2}$ & 11.67 & 145.97 \\
\hline 16. & $\mathrm{CdCl}_{2}$ & 12.07 & 179.58 \\
\hline
\end{tabular}




\begin{tabular}{llcc}
\hline 17. & $\mathrm{HgCl}_{2}$ & 11.61 & 140.92 \\
18. & Toluene & 10.57 & 53.53 \\
19. & Chloroform & 10.98 & 87.98 \\
20. & $\mathrm{CaCl}_{2}$ & 14.22 & 360.25 \\
21. & Triton X-100 & 13.97 & 339.24 \\
22. & EDTA & 13.95 & 337.56 \\
23. & PMSF $(10 \mathrm{mM})$ & 6.04 & 0 \\
24. & N-ethyl maleimide & 14.44 & 378.74 \\
25. & Acetone & 10.83 & 75.38 \\
\hline '- No proteolysis; SDS: sodium dodecyl sulphate; PMSF: phenyl-methyl-sulfonyl-fluoride;
\end{tabular}

EDTA: ethylene-diamine-tetra-acetic acid (EDTA); DMSO: dimethyl sulfoxide

To optimize the respective protease assay, several factors which could contribute to improve the efficiency of protease assay were reviewed. The proteinaceous substrate for protease assay must be completely soluble in buffer for accurate analysis; otherwise their compact native conformation and insensitivity to protease action may inadvertently generate errors. Casein starts precipitating below $\mathrm{pH} 6$; hence, it is used to assay neutral or alkaline proteases while haemoglobin is suitable for acidic proteases.

In current assay, agarose $(2 \%)$ was used as a solidifying agent; it forms porous gel which allows the diffusion of protein molecules. Agarose has several advantages over agar- (i) the zone of proteolysis on casein-agarose plate is clear and transparent as compared to a zone of proteolysis developed on substrate-agar plate, (ii) the proteolysis zone can easily perceived without a detection reagents and (iii) agarose has neutral charge and less chemically complex and less likely to interact other biomolecules. The impurities associated with agar might interfere and restrict with the development of clear zone.

Table 2 Proteolytic zones on single substrate-agarose plate and corresponding protease activities of treated trypsin

\begin{tabular}{|c|c|c|c|}
\hline \multirow{2}{*}{$\begin{array}{l}\text { Sr. } \\
\text { No. }\end{array}$} & \multirow{2}{*}{$\begin{array}{l}\text { Activator/ inhibitor/organic } \\
\text { solvents/salts }\end{array}$} & \multicolumn{2}{|c|}{ Trypsin } \\
\hline & & $\begin{array}{c}\text { Zone of } \\
\text { proteolysis }(\mathrm{mm})\end{array}$ & $\begin{array}{c}\text { Protease activity } \\
(\mathrm{U} / \mathrm{mL})\end{array}$ \\
\hline 1. & Control & 14.32 & 143.73 \\
\hline 2. & $\mathrm{HgCl}_{2}$ & 11.13 & - \\
\hline 3. & Pyridine & 11.94 & - \\
\hline 4. & Benzene & 15.06 & 188.31 \\
\hline 5. & $\mathrm{MgCl}_{2}$ & 13.54 & 96.75 \\
\hline 6. & $\mathrm{NaCl}(5 \mathrm{mM})$ & 14.37 & 146.75 \\
\hline 7. & $\mathrm{KCl}$ & 14.27 & 140.72 \\
\hline 8. & Butanol & 14.76 & 170.24 \\
\hline 9. & PMSF (10 mM) & 11.23 & - \\
\hline 10. & $\mathrm{NaCl}(150 \mathrm{mM})$ & 13.36 & 85.9 \\
\hline 11. & Glycerol & 14.32 & 143.73 \\
\hline 12. & SDS & 12.47 & 32.29 \\
\hline 13. & DMSO & 14.06 & 128.07 \\
\hline 14. & $\mathrm{ZnCl}_{2}$ & 13.58 & 99.16 \\
\hline 15. & $\mathrm{CuCl}_{2}$ & 13.77 & 110.6 \\
\hline 16. & $\mathrm{CdCl}_{2}$ & 13.24 & 78.67 \\
\hline 17. & PMSF (5 mM) & 11.93 & - \\
\hline 18. & Toluene & 15.43 & 210.6 \\
\hline 19. & Chloroform & 14.01 & 125.06 \\
\hline 20. & $\mathrm{CaCl}_{2}$ & 13.92 & 119.64 \\
\hline 21. & Triton X-100 & 14.63 & 162.41 \\
\hline 22. & EDTA & 13.39 & 87.71 \\
\hline 23. & $n$-dodecane & 6.02 & - \\
\hline 24. & N-ethyl maleimide & 14.03 & 126.27 \\
\hline 25. & Acetone & 12.79 & 51.57 \\
\hline
\end{tabular}

EDTA: ethylene-diamine-tetra-acetic acid (EDTA); DMSO: dimethyl sulfoxide

\section{CONCLUSION}

Although, Montville (1983) reported the dual-substrate (casein and gelatin) plate diffusion assay for quantitative estimation of endopeptidase units, the simultaneous degradation of gelatin with casein could alter the composition and solubility of medium. The present report describes novel technique to quantitate the enzyme units using single substrate-agarose plate diffusion method. The sophisticated protocols can be pursued for characterizing other protease variants. Presently, various applications of proteases in food, pharmaceutical and biotechnological sectors are continuously explored. This newly suggested method could be much more appropriate to characterize the protease for academic, research and commercial purpose. The rapid, sensitive and reliable protease assay method could serve the purpose of selection and screening of several proteases for their suitable exploration in the industrial sector. This substrate-agarose plate protease assay method could be efficiently useful to characterize the proteases obtained from other microbial, animal or plant sources.
Acknowledgments: We gratefully acknowledge the financial support of DSTSERB, New Delhi under Fast Track Project Scheme (SB/FT/LS-334/2012).

\section{REFERENCES}

Anson, M. L. (1938). The estimation of pepsin, trypsin, papain and cathepsin with hemoglobin. Journal of General Physiology, 22, 79-89.

Barrett, A. J., Rawlings, N. D. (2001). Evolutionary lines of cysteine

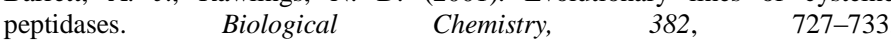
http://dx.doi.org/10.1515/BC.2001.088.

Blanco, M., Simpson, B. K., Perez-Martin, R. I., \& Sotelo, C. G. (2014) Isolation and partial characterization of trypsin from pancreas of small-spotted catshark (Scyliorhinus canicula). Journal of Food Biochemistry, 38, 196-206. http://dx.doi.org/10.1111/jfbc. 12038 .

Gallahgher, S. R., Carroll, E. J., \& Leonard, R. T. (1986). A sensitive diffusion plate assay for screening inhibitors of protease activity in plant cell fractions. Plant Physiology, 81, 869-874.

Hagihara, B. (1958). The enzymes, In: Boyer, P.D., Lardy, H., Myrbxck, K (eds), Academic Press Inc, New York.

Indian Pharmacopoeia. (2014). Microbiological assay of antibiotics. In: Indian Pharmacopoeia. The Indian Pharmacopoeia Commission, Ghaziabad, 1, 50-58. Jarocki, V. M., Tacchi, J. L., \& Djordjevic, S. P. (2015). Non-proteolytic functions of microbial proteases increases pathological complexity. Proteomics, 15,1075-1088. http://dx.doi.org/10.1002/pmic.201400386.

Kunitz, M. (1947). Crystalline soybean trypsin inhibitor. Journal of General Physiology, 30, 291-310.

Li, Q., Yi, L., Marek, P., \& Iverson, B. L. (2013). Commercial proteases: present and future. FEBS Letters, 587, 1155-1163. http://dx.doi.org/10.1016/j.febslet.2012.12.019.

Lu, J., Wu, X., Jiang, Y., Cai, X., Huang, L., Yang, Y., Wang, H., Zeng, A., \& Li, A. (2013). An extremophile Microbacterium strain and its protease production under alkaline conditions. Journal of Basic Microbiology, 54, 378385. http://dx.doi.org/10.1002/jobm.201200553.

Mokashe, N., Chaudhari, A., \& Patil, U. (2015). Optimal production and characterization of alkaline protease from newly isolated halotolerant Jeotgalicoccus sp. Biocatalalysis Agricultural and Biotechnology, 4, 235-243. http://dx.doi.org/10.1016/j.bcab.2015.01.003.

Montville, T. J. (1983). Dual-substrate plate diffusion assay for proteases. Applied and Environmental Microbiology, 45,200-204.

Morris, L. S., Evans, J., \& Marchesi, J. R. (2012). A robust plate assay for detection of extracellular microbial protease activity in metagenomic screens and pure cultures. Journal of Microbiological Methods, 91, 144-146. http://dx.doi.org/10.1016/j.mimet.2012.08.006.

Nakanishi, T., Matsumura, Y., Minamiura, N., \& Yamamoto, T. (1974). Action and specificity of Streptomyces alkalophilic proteinase. Agricultural and Biological Chemistry, 38, 37-44. http://dx.doi.org/10.1080/00021369.1974.10861520.

Patil, U., Chaudhari, A. (2010). Studies on novel thermostable and solvent tolerant alkaline protease from bacteria, $\mathrm{PhD}$ Thesis.

Patil, U., Mokashe, N., \& Chaudhari, A. (2016). Detergent compatible, organic solvent tolerant alkaline protease from Bacillus circulans MTCC 7942: Purification and characterization. Preparative Biochemistry and Biotechnology, 46, 56-64. http://dx.doi.org/10.1080/10826068.2014.979205.

Shimogaki, H., Takeuchi, K., Nishino, T., Ohdera, M., Kudo, T., Ohba, K., Iwama, M., \& Irie, M. (1991). Purification and properties of a novel surface active agent and alkaline-resistant protease from Bacillus sp. Agricultural and Biological Chemistry, 55, 2251-2258. http://doi.org/10.1271/bbb1961.55.2251. Sumantha, A., Larroche, C., \& Pandey, A. (2006). Microbiology and industrial biotechnology of food-grade proteases: A perspective. Food Technology and Biotechnology, 44, 211-220,

Vermelho, B. A., Meirelles, M. N., Lopes, A., Petinate, S., Chaia, A. A., \& Branquinha, M. H. (1996). Detection of extracellular protease from microorganisms on agar plates. Memórias do Instituto Oswaldo Cruz, 91, 755760. http://dx.doi.org/10.1590/S0074-02761996000600020.

Vijayaraghavan, P., Vincent, S. G. P. (2013). A simple method for the detection of protease activity on agar plates using bromocresol green dye. Journal of Biochemistry and Technology, 4, 628-630. 